\title{
Mesolimbic Dopamine Super-Sensitivity in Melanin- Concentrating Hormone-1 Receptor-Deficient Mice
}

\author{
Daniel G. Smith, Eleni T. Tzavara, Janice Shaw, Susan Luecke, Mark Wade, Richard Davis, Craig Salhoff, \\ George G. Nomikos, and Donald R. Gehlert \\ Neuroscience Discovery Research, Lilly Research Laboratories, Eli Lilly and Company, Indianapolis, Indiana 46285
}

\begin{abstract}
Melanin-concentrating hormone $(\mathrm{MCH})$ neurons and $\mathrm{MCH}-1$ receptors $(\mathrm{MCH} 1 \mathrm{r})$ densely populate mesolimbic dopaminergic brain regions such as the nucleus accumbens (NAc). The regulation of dopamine by MCH1r was suggested to be an important mechanism underlying the hyperactive phenotype of MCH1r knock-out (ko) mice. However, MCH1r modulation of monoamine neurotransmission has yet to be examined. We tested whether dopamine, norepinephrine, and serotonin function is dysregulated in MCH1r ko and wild-type (wt) mice. MCH1r ko mice exhibited robust hyperactivity in a novel or familiar environment and were super-sensitive to the locomotor activating effects of D-amphetamine and the $\mathrm{D}_{1}$ agonist 2,3,4,5-tetrahydro-7,8-dihydroxy-1-phenyl-1H-3-benazepine $\mathrm{HCl}_{\text {. The }} \mathrm{D}_{2}$ agonist, quinpirole, decreased locomotion similarly in both ko and wt mice. Tissue contents of dopamine within the NAc and caudate-putamen were not significantly different in ko compared with wt mice. Basal and amphetamine-evoked NAc dopamine, norepinephrine, and serotonin efflux, as measured using in vivo microdialysis, were not significantly different between genotypes. In contrast, $\mathrm{D}_{1}$-like and $\mathrm{D}_{2}$-like receptor binding were significantly higher within the olfactory tubercle, ventral tegmental area, and NAc core and shell of ko mice. Norepinephrine transporter (NET) binding was significantly elevated within the NAc shell and globus pallidus of ko mice, whereas serotonin transporter binding was decreased in the NAc shell. Thus, deletion of MCH1r results in an upregulation of mesolimbic dopamine receptors and NET, indicating that MCH1r may negatively modulate mesolimbic monoamine function. MCH1r may be an important therapeutic target for neuropsychiatric disorders involving dysregulation of limbic monoamine systems.
\end{abstract}

Key words: melanin-concentrating hormone-1 receptor; mesolimbic; nucleus accumbens; dopamine; norepinephrine; hyperactivity; knock-out mice

\section{Introduction}

The lateral hypothalamic neuropeptide melanin-concentrating hormone $(\mathrm{MCH})$ is an important modulator of food intake and energy balance (Nahon, 1994; Saper et al., 2002). MCH infusion into the brain induces feeding in rats (Qu et al., 1996; Rossi et al., 1997), and mice with an ablation of the MCH gene are hypophagic, hypermetabolic, and lean (Shimada et al., 1998). Transgenic mice that overexpress $\mathrm{MCH}$ are hyperphagic and obese (Ludwig et al., 2001). The effects of MCH are mediated via two G-proteincoupled receptors, MCH1r (Chambers et al., 1999; Saito et al., 1999) and MCH2r (An et al., 2001; Sailer et al., 2001), although only MCH1r is functional in rodents (Tan et al., 2002). MCH1r knock-out (ko) mice are hyperactive, are hypermetabolic, have reduced fat mass, insulin, and leptin levels, and are mildly hyperphagic (Chen et al., 2002; Marsh et al., 2002). The slight increase in feeding in MCH1r ko mice is most likely an effect of increased locomotor and metabolic activity. MCH1r antagonists attenuate $\mathrm{MCH}$-induced feeding, reduce consumption of highly palatable food, and decrease body weight in rats with diet-

Received July 29, 2004; revised Dec. 7, 2004; accepted Dec. 10, 2004.

Correspondence should be addressed to Dr. Daniel G. Smith, Neuroscience Discovery Research, Lilly Research Laboratories, Eli Lilly and Company, Indianapolis, IN 46285. E-mail: dgsmith@lilly.com.

DOI:10.1523/JNEUROSCI.4079-04.2005

Copyright $\odot 2005$ Society for Neuroscience $\quad$ 0270-6474/05/250914-09\$15.00/0 induced obesity (Borowsky et al., 2002; Takekawa et al., 2002). Therefore, the MCH1r plays a key role in energy homoeostasis.

$\mathrm{MCH}$-containing fibers (Bittencourt et al., 1992) from the lateral hypothalamus and MCH1r expression (Hervieu et al., 2000; Saito et al., 2001) are abundant in mesolimbic dopamine structures such as the nucleus accumbens (NAc), olfactory tubercle (OT), and ventral tegmental area (VTA). The role of dopamine in the regulation of locomotor activity is well known, and $\mathrm{MCH} 1 \mathrm{r}$ interaction with dopamine systems may underlie the hyperactive phenotype of MCH1r ko mice (Marsh et al., 2002). Furthermore, the mesolimbic dopamine system projecting from the VTA to the NAc has a widely recognized role in processing responses to drugs of abuse (Wise and Bozarth, 1985; Koob and Bloom, 1988) and food reinforcers (Hoebel et al., 1989; Kelley and Berridge, 2002). Thus, it was proposed that MCH1r may regulate responses to rewarding stimuli (Saper et al., 2002; DiLeone et al., 2003).

$\mathrm{MCH} 1 \mathrm{r}$ localization within limbic brain regions (e.g., NAc) also provides a neurobiological substrate for MCH1r modulation of norepinephrine and serotonin, neurotransmitters with chief roles in regulating affective disorders (Ressler and Nemeroff, 2000). In animal models of depression and anxiety, an MCH1r antagonist mirrored the effects of known antidepressant and anxiolytic drugs (Borowsky et al., 2002).

An attempt to discover a direct relationship between the 
MCH1r and monoamine neurotransmitter systems has not been described. We hypothesized that the MCH1r negatively modulates the mesolimbic dopamine system and that an altered dopaminergic state provides a neurobiological basis for the MCH1r ko mouse phenotype. The objectives of the present study were as follows: (1) to evaluate basal and evoked locomotor activity in MCH1r ko and wild-type (wt) mice; (2) to determine basal and evoked tissue levels and extracellular concentrations of dopamine, norepinephrine, and serotonin within the NAc of MCH1r ko and wt mice; and (3) to quantify dopamine receptors and the dopamine, norepinephrine, and serotonin transporters in MCH1r ko and wt mice.

\section{Materials and Methods}

Animals. All experiments were performed according to the policies of the Animal Care and Use Committee of Eli Lilly and Company, in conjunction with the American Association for the Accreditation of Laboratory Animal Care-approved guidelines. Animals were individually housed in an environmentally controlled facility in which food and water were available ad libitum. They were maintained on a $12 \mathrm{~h}$ light/dark cycle (7:30 A.M. to 7:30 P.M.), and all procedures were performed during the light period.

Adult male wt and MCH1r ko mice were generated on a 129SvEv $\times$ C57BL/6 hybrid background by homologous recombination as described previously (Chen et al., 2002). Genotyping was performed by PCR analysis on mouse-tail DNA. Mice were 3-5 months of age and weighed $30-35 \mathrm{~g}$ during testing.

Basal and evoked locomotor activity in MCH1r ko and wt mice. Ambulations, defined as the sequential breaking of adjacent photobeams, were measured with a 20-station Photobeam Activity System (San Diego Instruments, San Diego, CA) with seven beams per station. To assess the effects of genotype on spontaneous locomotor activity during habituation to a novel environment and during re-exposure to the same environment $4 \mathrm{~h}$ later, mice ( $n=31-33$ per genotype) were individually placed into an activity station for $60 \mathrm{~min}$, returned to their home cages for $4 \mathrm{~h}$, and then placed back into the activity station for $60 \mathrm{~min}$. After $2 \mathrm{~d}$, mice were placed into the activity-monitoring stations for a habituation period of $20 \mathrm{~min}$, were injected $(0.1 \mathrm{ml} / 10 \mathrm{~g}$ volume, i.p. $)$ with saline, the $\mathrm{D}_{1}$ receptor agonist 2,3,4,5-tetrahydro-7,8-dihydroxy-1-phenyl-1H-3benazepine $\mathrm{HCl}$ (SKF-38393) ( $9 \mathrm{mg} / \mathrm{kg} ; n=13$ per genotype; SigmaAldrich, St. Louis, MO), or the indirect dopamine agonist, D-amphetamine (AMPH; $0,3 \mathrm{mg} / \mathrm{kg} ; n=9-10$ per group), and were returned to the stations for $60 \mathrm{~min}$. A $9 \mathrm{mg} / \mathrm{kg}$ dose of SKF-38393 was selected because it was a subthreshold dose in a preliminary dose-response study of locomotor activity in C57BL/6 mice (our unpublished results). A second set of MCH1r ko and wt mice ( $n=9-10$ per group) was tested according to the same protocol (i.e., two $60 \mathrm{~min}$ sessions followed by a $20 \mathrm{~min}$ habituation period and a 60 min test period $2 \mathrm{~d}$ later) but was injected with 1 or $2 \mathrm{mg} / \mathrm{kg}$ AMPH between the $20 \mathrm{~min}$ habituation period and the $60 \mathrm{~min}$ test session. A third set of MCH1r ko and wt mice ( $n=7-12$ per genotype) was used to test the effects of the $\mathrm{D}_{2}$ receptor agonist quinpirole $(0.01,0.1,1,10 \mathrm{mg} / \mathrm{kg}$, i.p.; SigmaAldrich) on locomotor activity according to the same protocol described above. Each mouse was used only once and received one dose of SKF-38393, AMPH, or quinpirole.

Data are expressed as mean \pm SEM ambulations in 5-min time bins or as the mean number of ambulations \pm SEM across 125 -min time bins (i.e., a 60-min test session). One-way ANOVA with repeated measures on environment (novel or familiar) was used to assess the effects of genotype on spontaneous locomotor activity (SPSS 10.0 statistical software; SPSS, Chicago, IL). The effects of AMPH, SKF-38393, and quinpirole were compared with their respective vehicle-treated control groups using separate genotype (ko vs wt) $\times$ dose (SKF-38393, 0, 9; AMPH, 0, 1, 2, 3; quinpirole, $0.01,0.1,1,10)$ two-factor ANOVAs.

Tissue content of monoamines and metabolites. MCH1r ko and wt mice ( $n=10$ per genotype) were injected $(0.1 \mathrm{ml} / 10 \mathrm{~g}$ volume, i.p.) with AMPH $(3 \mathrm{mg} / \mathrm{kg})$ or $0.9 \%$ saline and killed after $30 \mathrm{~min}$. NAc and caudate-putamen $(\mathrm{CPu})$ tissue from $\mathrm{MCH} 1 \mathrm{r}$ ko and wt mice was sonicated in $\sim 10$ volumes $0.1 \mathrm{~N}$ TCA. Samples were vortexed and then cen-

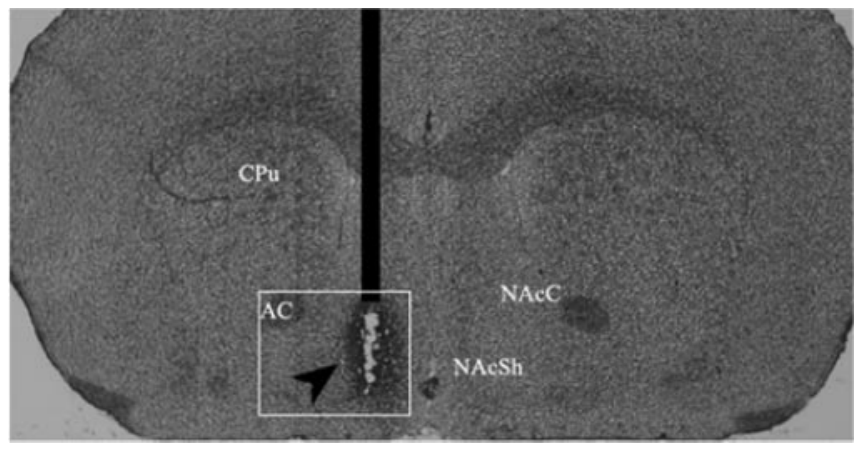

Figure 1. Representative coronal brain section illustrating the location of $1 \mathrm{~mm}$ active dialysis membrane (arrowhead) of microdialysis probe within the NAc of MCH1r ko and wt mice. The black bar indicates the path of the probe. The boundaries of probe locations for inclusion in data analysis are outlined (rectangle). AC, Anterior commissure.

trifuged at $12,000 \times g$ for $2 \mathrm{~min}$. Supernatants were collected and analyzed for dopamine, norepinephrine, serotonin, the dopamine metabolites dihydroxyphenylacetic acid (DOPAC) and homovanillic acid (HVA), the norepinephrine metabolite 3-methoxy, 4-hydroxyphenylglycol (MHPG), and the serotonin metabolite 5-hydroxyindolacetic acid (5-HIAA) concentrations using HPLC coupled with electrochemical detection (HPLC-EC). Monoamines and metabolites were separated with a base deactivated silicaHypersil $5 \mu \mathrm{m}$ C18 analytical column $(4.6 \times 150 \mathrm{~mm}$; Keystone Scientific, Bellefonte, PA) with a mobile phase consisting of 75 mm sodium phosphate monobasic, $350 \mathrm{mg} / \mathrm{L}$ 1-octanesulfonic acid sodium salt, $0.5 \mathrm{~mm}$ EDTA, $0.8 \%$ tetrahydrofuran (HPLC grade, inhibitor-free), and $8 \%$ acetonitrile, $\mathrm{pH}$ 3 (adjusted with phosphoric acid), at a flow rate of $1.2 \mathrm{ml} / \mathrm{min}$. An electrochemical detector (EG \& G PARC, Princeton, NJ) with dual glassy carbon electrodes was used (electrode $1=680 \mathrm{mV}$, range, $0.5 \mathrm{nA}$; electrode $2=-100 \mathrm{mV}$, range, $0.2 \mathrm{nA}$ ). Data were collected using EZChrom software (Scientific Software, San Ramon, CA) that calculated peak heights and sample concentrations. The sensitivity for monoamine and metabolites was $0.1 \mathrm{pmol} / \mathrm{ml}$.

In vivo microdialysis. Mice were anesthetized with ketamine (100 mg/ $\mathrm{kg})$ and xylazine $(0.2 \mathrm{mg} / \mathrm{kg})$, placed in a stereotaxic apparatus, and implanted unilaterally with $1 \mathrm{~mm}$ microdialysis probes (CMA Microdialysis, North Chelmsford, MA) aimed at the NAc (anteroposterior, +1.3; mediolateral, +0.6; dorsoventral, -5 ) (Franklin and Paxinos, 1997). Visible Light Cured Restorative (Henry Schein, Melville, NY), anchored by two stainless steel screws (Bioanalytical Systems, West Lafayette, IN), was used to affix the probe to the skull. Animals were left to recover for 24-36 h.

On test day, mice ( $n=11-15$ per genotype) were transferred to a separate environmentally controlled room connected to a liquid swivel perfusion system for use with freely moving animals (Bioanalytical Systems), and artificial CSF (aCSF) (composition in mM: $150 \mathrm{NaCL}, 3 \mathrm{KCl}$, $1.7 \mathrm{CaCl}, 0.9 \mathrm{MgCl}_{2}, \mathrm{pH} 6.0$ ) was perfused through the probe with a syringe pump (Bioanalytical Systems) at a rate of $1 \mu \mathrm{l} / \mathrm{min}$ for a $2 \mathrm{~h}$ acclimation period. Immediately after the acclimation period, $30 \mathrm{~min}$ samples were collected for $2 \mathrm{~h}$ to establish baseline dialysate concentrations. Animals were then injected with saline $(0.1 \mathrm{ml} / 10$ g, i.p. $)$, and samples were collected for $2.5 \mathrm{~h}$. Next, animals were injected with AMPH ( 1 or $3 \mathrm{mg} / \mathrm{kg}$, i.p., in saline; Sigma-Aldrich), and $30 \mathrm{~min}$ samples were collected for an additional $2.5 \mathrm{~h}$.

Dialysates were collected into refrigerated fraction collectors (Bioanalytical Systems) and analyzed the same day with HPLC-EC as described previously (Perry and Fuller, 1997). The sensitivity for dopamine, norepinephrine, and serotonin was $0.1 \mathrm{pmol} / \mathrm{ml}$ dialysate or $2 \mathrm{fmol} / \mathrm{sample}$ $(20 \mu \mathrm{l})$. At the end of the experiment, animals were killed by $\mathrm{CO}_{2}$ inhalation, and cresyl violet dye was perfused through the probes to mark the location (Fig. 1). Brains were removed and sliced into $30 \mu \mathrm{m}$ coronal sections for histological verification of probe placement.

Basal dialysate concentrations of dopamine, norepinephrine, serotonin, DOPAC, HVA, MHPG, and 5-HIAA levels, expressed in nanomol/ liter, were calculated for each animal from the average of the last three 
baseline samples using conventional microdialysis. One-way ANOVA was used to analyze the effects of genotype (MCH1r ko, wt) on basal monoamine and metabolite levels. The effects of the administration of saline and AMPH on dopamine, norepinephrine, serotonin, DOPAC, HVA, MHPG, and 5-HIAA dialysate concentrations were analyzed using ANOVA. The last four vehicle samples for each group (ko, $+0,1$, or 3 $\mathrm{mg} / \mathrm{kg}$ AMPH; wt, $+0,1$, or $3 \mathrm{mg} / \mathrm{kg} \mathrm{AMPH}$ ) were averaged and compared with the average of the first four samples after the injection of AMPH.

Quantitative low-perfusion rate microdialysis was used to estimate the absolute extracellular concentration of dopamine, norepinephrine, serotonin, DOPAC, HVA, MHPG, and 5-HIAA (Smith et al., 1992; Wang et al., 1997; Gerber et al., 2001). At very slow perfusion flow rates, the perfusion medium nears equilibrium with the extracellular fluid, and the concentration of neurotransmitters and metabolites in low-perfusion rate dialysate samples parallels the extracellular environment. In the present study, MCH1r ko $(n=6)$ and wt $(n=4)$ mice were connected to the liquid swivel perfusion system as described above, and aCSF (composition in mu: $150 \mathrm{NaCL}, 3 \mathrm{KCl}, 1.7 \mathrm{CaCl}, 0.9 \mathrm{MgCl}_{2}, \mathrm{pH} 6.0$ ) was perfused through the probe at a flow rate of $50 \mathrm{nl} / \mathrm{min}$ for $7-8 \mathrm{~h}$. Dialysate samples were collected and analyzed according to the procedure described above. ANOVA was used to compare the extracellular concentrations of neurotransmitters and metabolites in ko and wt mice.

Autoradiographic receptor localization. Radioligands were obtained from NEN (Boston, MA). Autoradiographic localization was performed according to protocols described previously: $\left[{ }^{3} \mathrm{H}\right]-8$-chloro-2,3,4,5tetrahydro-3-5-1h-3-benzazepin-7-ol (SCH23390) (Dawson et al., 1986), $\left[{ }^{3} \mathrm{H}\right]$-raclopride (Knable et al., 1994a,b), [ $\left.{ }^{3} \mathrm{H}\right]$-[2( $\beta$ )-carbomethoxy-3( $\left.\beta\right)$ (4-fluorophenyl)-tropane] (WIN35,428) (Gehlert and Schoepp, 1992), $\left[{ }^{3} \mathrm{H}\right]$-nisoxetine (Gehlert et al., 1995), and $\left[{ }^{3} \mathrm{H}\right]$-citalopram (Gehlert et al., 1995).

After incubation, brain sections were rinsed in buffer, dipped in icecold distilled water, and quickly dried with a stream of cool air. Dried sections and radioactive standards (3H-Microscales; Amersham Biosciences, Piscataway, NJ) were apposed to phosphoimager plates and scanned on a phosphoimager (Bioanalytical Systems). Image analysis was performed using MCID Elite image analysis system (Imaging Research, Ontario, Canada). Brain areas were delineated according to the mouse brain atlas of Franklin and Paxinos (1997). A minimum of four bilateral readings were taken for each region for each animal $(n=5$ per genotype). Specific binding was determined by subtraction of nonspecific binding (obtained by incubating adjacent sections with the addition of a saturating concentration of displacer) from total binding. The mean values of readings taken in each region for each individual animal were grouped by genotype and analyzed by region using unpaired, two-tailed $t$ tests with a significance level of $p<0.05$. Data are presented as mean \pm SEM in nanoCurie per milligram plastic using the calibration with the radioactive standards.

\section{Results}

Elevated basal and evoked locomotor activity in MCH1r ko mice

In a previous study, MCH1r ko mice were reported to exhibit increased locomotor activity (Marsh et al., 2002). To extend these findings, we tested the hypothesis that MCH1r ko and wt mice would exhibit a greater novel environment-induced locomotor response and that this hyperactivity would persist despite habituation to the environment. We found that MCH1r ko mice showed markedly higher basal locomotor activity over $60 \mathrm{~min}$ when exposed to a novel environment and when re-exposed to the same environment $4 \mathrm{~h}$ later, compared with wt mice (Fig. 2). The average number of ambulations across six 10-min time bins in the novel environment (ko, $66 \pm 4.4$; wt, $51 \pm 4.3$ ) or familiar environment (ko, $40 \pm 5$; wt, $22 \pm 5$ ) was significantly higher in ko than wt mice (novel, $F_{(1,62)}=6, p=0.02$; familiar, $F_{(1,62)}=$ $6.5, p=0.01)$. Activity levels decreased $\sim 50 \%$ from the first (novel environment) to the second (familiar environment) loco-
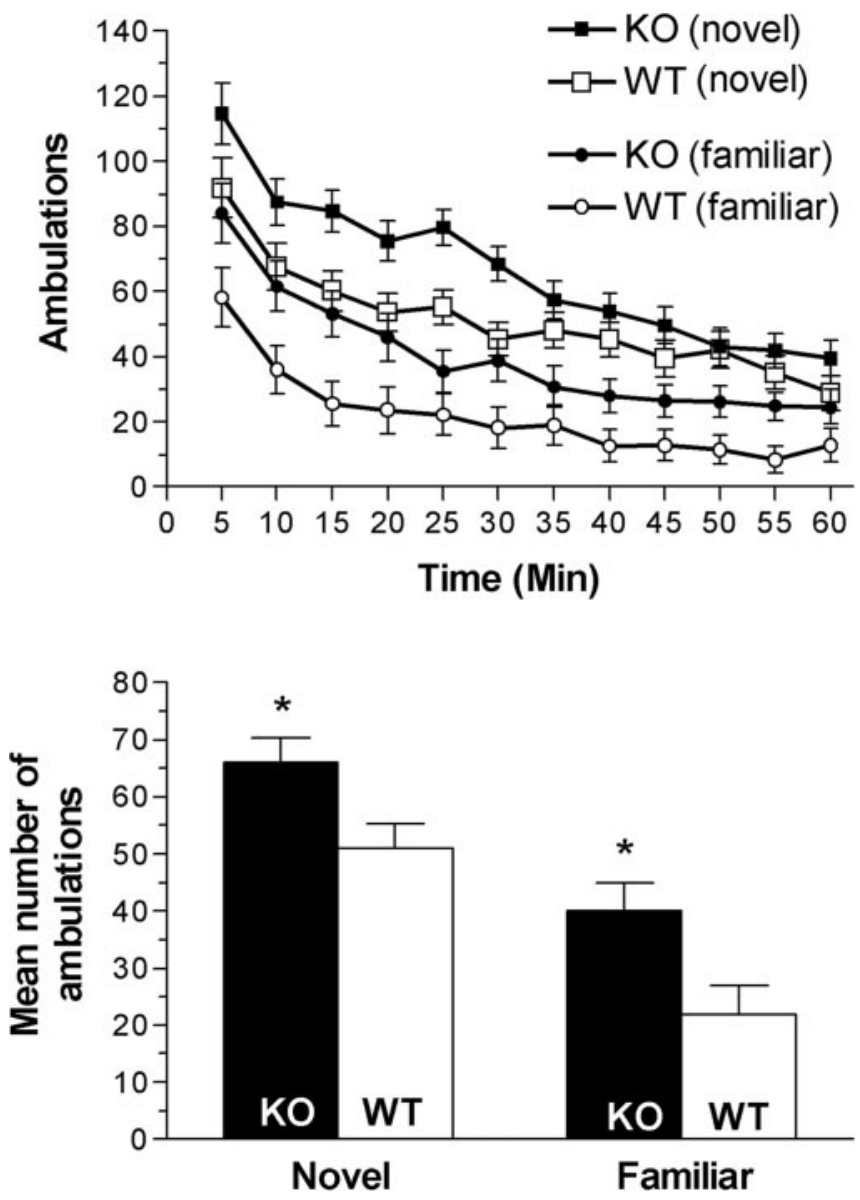

Figure 2. MCH1r ko mice exhibit basal hyperactivity in a novel or familiar environment. $A$, Time course of the locomotor response and mean ambulations over 60 min in MCH1r ko (KO) and wt (WT) mice. Data represent the mean number of ambulations \pm SEM in 31-33 mice per genotype. ${ }^{*} p<0.05$ ko versus wt mice.

motor test in both ko and wt mice, indicating that betweensession habituation was intact in MCH1r ko mice.

Elevated basal locomotor activity may be indicative of dysfunctional mesolimbic dopamine circuitry. Thus, the locomotor responses to SKF-38393 (9 mg/kg, i.p.), AMPH (1, 2, $3 \mathrm{mg} / \mathrm{kg}$, i.p.), and quinpirole $(0.01,0.1,1,10 \mathrm{mg} / \mathrm{kg}$, i.p.) were measured in separate groups of MCH1r ko and wt mice (i.e., each mouse received only one dose of either SKF-38393, AMPH, or quinpirole).

\section{SKF-38393 super-sensitivity in MCH1r ko mice}

The administration of SKF-38393 (9 mg/kg, i.p.) did not affect locomotor activity in wt mice, whereas ko mice were six times more active than vehicle-injected ko mice (Fig. $3 A$ ). A genotype $\times$ dose of SKF-38393 two-factor ANOVA revealed a significant main effect of genotype $\left(F_{(1,21)}=5.1 ; p=0.03\right)$, whereas the main effect of dose $\left(F_{(1,21)}=1.7 ; p=0.2\right)$ and the genotype $\times$ dose interaction $\left(F_{(1,21)}=2.6 ; p=0.1\right)$ were not significant.

\section{AMPH super-sensitivity in MCH1r ko mice}

The administration of $3 \mathrm{mg} / \mathrm{kg}$ AMPH produced a robust increase in ambulations in MCH1r ko and wt mice (Fig. $3 B$ ). The magnitude of the increase in activity was more than threefold greater in ko $(+2000 \%)$ than wt $(+300 \%)$ mice, when compared with their respective vehicle-injected control groups. Furthermore, $2 \mathrm{mg} / \mathrm{kg}$ AMPH was ineffective in wt mice but produced a 

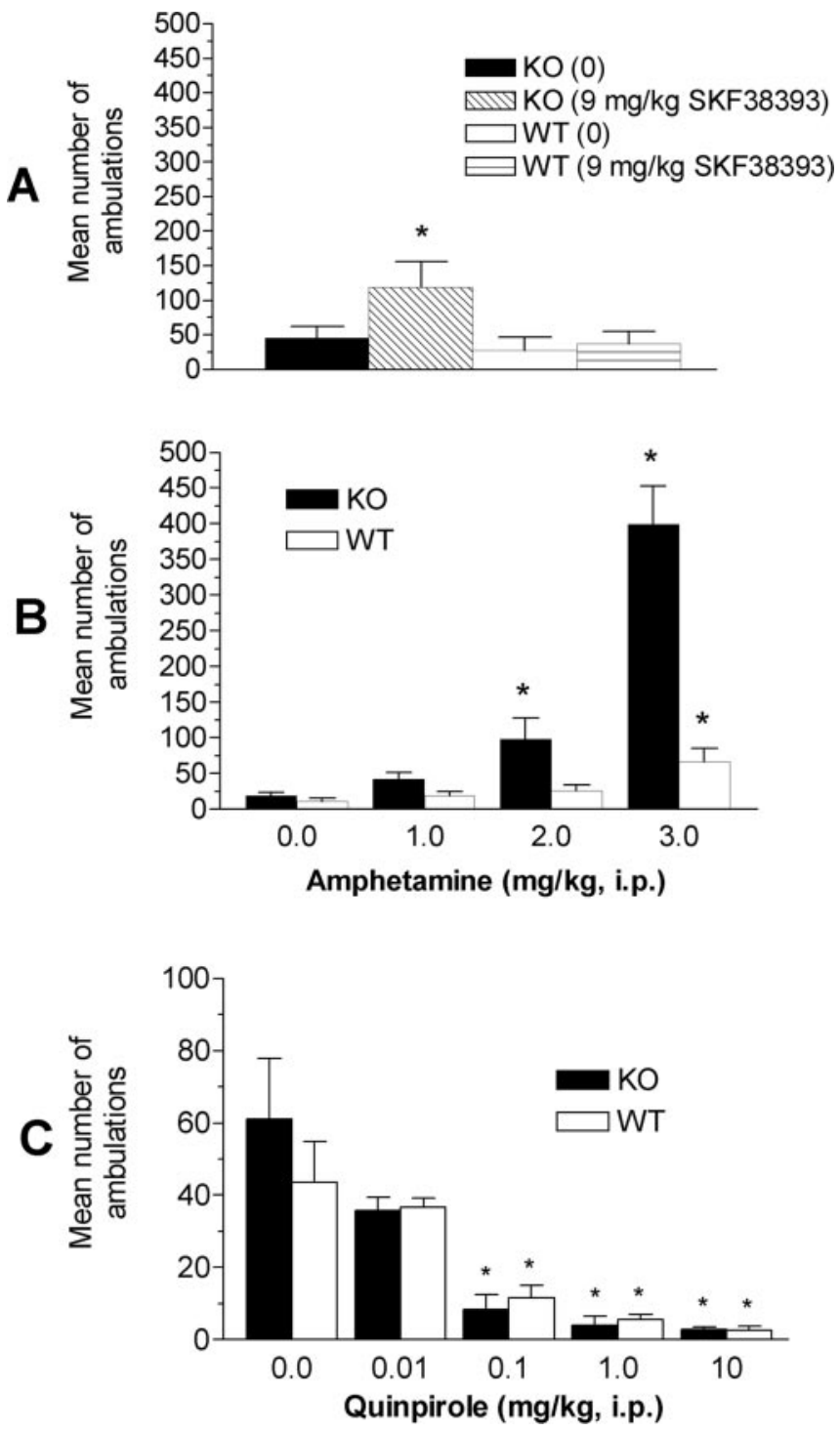

Figure 3. MCH1r ko mice are super-sensitive to $D_{1}$ agonist (SKF-38393)-evoked or AMPHevoked locomotor activity but not to the activity-suppressing effect of $D_{2}$ stimulation by quinpirole. The data represent the mean number of ambulations \pm SEM in MCH1r ko and wt mice for $60 \mathrm{~min}$ after the administration of SKF-38393 ( $A$ ) ( $9 \mathrm{mg} / \mathrm{kg}$, i.p.; $n=13$ per group), AMPH (B) (1-3 mg/kg, i.p.; $n=9-10$ per group), or the $D_{2}$ agonist quinpirole $(C)(0.01-10 \mathrm{mg} / \mathrm{kg}$, i.p.; $n=9-12$ per group). ${ }^{*} p<0.05$ versus respective vehicle-treated animals.

significant $(p<0.05)$ increase in ambulations in MCH1r ko mice. No significant effect on ambulations was observed after the administration of $1 \mathrm{mg} / \mathrm{kg}$ AMPH in ko or wt mice. A genotype $\times$ AMPH dose two-factor ANOVA indicated significant main effects of genotype $\left(F_{(1,67)}=46.4 ; p<0.001\right)$ and dose $\left(F_{(3,67)}=\right.$ 39.7; $p<0.001)$ and a significant genotype $\times$ dose interaction $\left(F_{(3,67)}=22.4 ; p<0.001\right)$. Post hoc Duncan's test revealed significant increases in ambulations in MCH1r ko mice after 2 and 3 $\mathrm{mg} / \mathrm{kg}$ and in wt mice after $3 \mathrm{mg} / \mathrm{kg} \mathrm{AMPH}$.

\section{Quinpirole-induced suppression of locomotor activity}

Quinpirole $(0.1,1$, and $10 \mathrm{mg} / \mathrm{kg}$ ) significantly reduced locomotor activity in MCH1r ko and wt mice (Fig. 3C). Using a twofactor (genotype $\times$ dose) ANOVA, there was a significant main effect of quinpirole dose $\left(F_{(4,82)}=13.7 ; p<0.001\right)$, whereas the effects of genotype $\left(F_{(1,82)}=0.2 ; p=0.7\right)$ and the genotype $\times$ dose interaction $\left(F_{(4,82)}=0.6 ; p=0.7\right)$ were not significant.
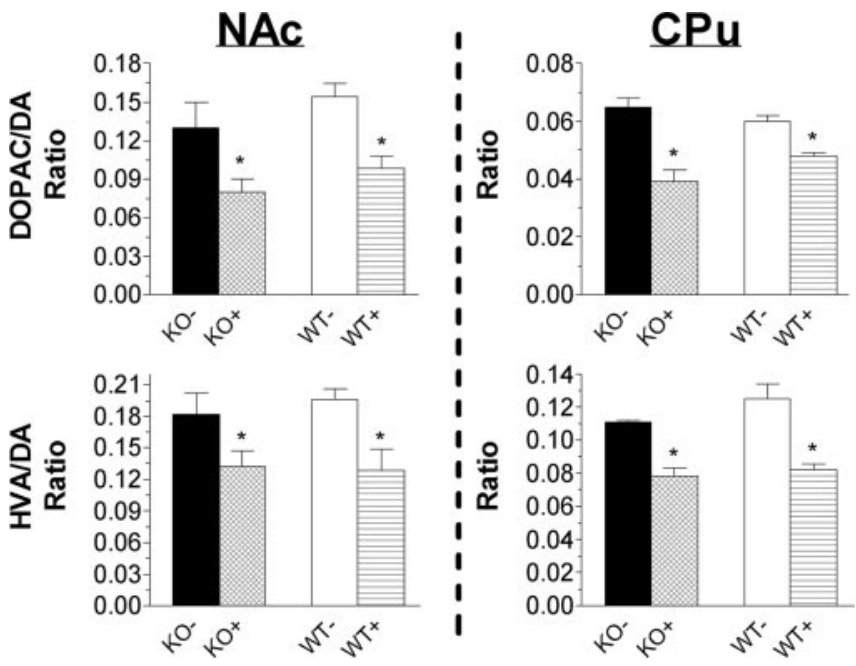

Figure 4. Tissue dopamine content is unchanged in MCH1r ko mice, compared with wt mice, after administration of vehicle (KO - WT) or $3 \mathrm{mg} / \mathrm{kg}$ (i.p.) amphetamine (KO+, WT+). HPLC analysis of dopamine, DOPAC, and HVA within the NAC and CPu of MCH1r ko and wt mice. Serotonin, MHPG, and 5-HIAA levels were not significantly different in ko compared with wt mice (data not shown). Data represent the ratio of the mean $\pm \mathrm{SEM} \mathrm{nmol} / \mathrm{g}$ tissue in five mice per genotype. ${ }^{*} p<0.05 \mathrm{AMPH}-\mathrm{evoked}(+)$ versus basal $(-)$.

One-way ANOVA was used to analyze the effect of dose across genotypes. The $0.1,1$, and $10 \mathrm{mg} / \mathrm{kg}$ doses, but not a $0.01 \mathrm{mg} / \mathrm{kg}$ dose, of quinpirole significantly reduced locomotor activity $\left(F_{(9,82)}=6.4 ; p<0.001\right)$.

\section{Basal and AMPH-evoked tissue and extracellular levels of monoamines and metabolites}

Increased basal locomotor activity and enhanced AMPH and $\mathrm{D}_{1}$ agonist-induced locomotor responses are indicative of enhanced dopaminergic neurotransmission within the mesolimbic dopamine system (Fink and Smith, 1980; Koob et al., 1981; Xu et al., 2000). To test the hypothesis that heightened dopamine function underlies the hyperactive phenotype of MCH1r ko mice, we used HPLC-EC to determine NAc and CPu tissue contents of dopamine, norepinephrine, serotonin, DOPAC, HVA, MHPG, and 5-HIAA. Basal tissue contents of dopamine, DOPAC, and HVA and the DOPAC/dopamine and HVA/dopamine ratios were unchanged in ko mice (Fig. 4). Similarly, AMPH-evoked tissue levels of dopamine, DOPAC, or HVA were not different in MCH1r ko compared with wt mice (i.e., a 20-40\% reduction in DOPAC/ dopamine and HVA/dopamine ratios was measure in ko and wt mice). There were no genotype-dependent differences in tissue contents of serotonin, MHPG, 5-HIAA, or the 5-HIAA/5-HT ratio within the $\mathrm{NAc}$ or $\mathrm{CPu}$ (data not shown). Norepinephrine tissue levels were below the detectable limits of our HPLC-EC system.

Although tissue dopamine content was unchanged in $\mathrm{MCH} 1 \mathrm{r}$ ko mice, the hyperactive phenotype may be associated with elevated extracellular dopamine concentration within the NAc. We used low-perfusion rate quantitative microdialysis (Smith et al., 1992; Wang et al., 1997; Gerber et al., 2001) and conventional in vivo microdialysis to assess basal efflux of dopamine, norepinephrine, serotonin, and levels of DOPAC, HVA, 5-HIAA, and MHPG within the NAc of MCH1r ko and wt mice. There were no statistically significant $\left(F_{(1,23)}=0.1-2.1 ; p=0.2-0.7\right)$ differences in basal levels of parent amines (Fig. 5) or metabolites (data not shown), as determined using the low-perfusion rate or conventional methods, between ko and wt mice. It is noteworthy that the 


\section{Low-perfusion flow rate}

Conventional microdialysis

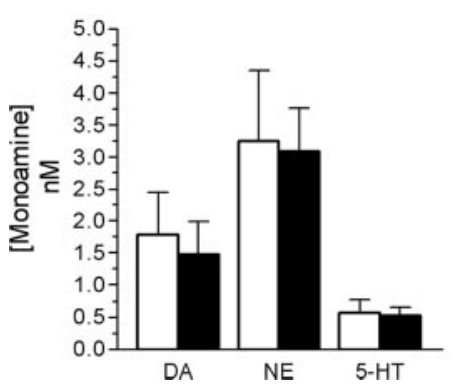

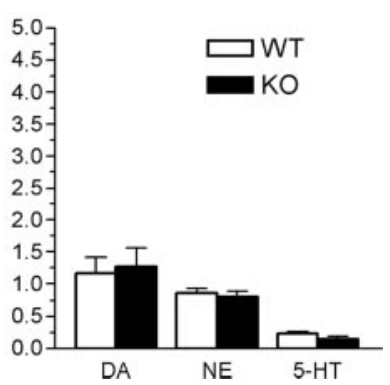

Figure 5. Basal concentrations of dopamine (DA), norepinephrine (NE), and serotonin (5$\mathrm{HT}$ ) within the NAc are unaltered in MCH1r ko mice. Parent monoamine and metabolite (data not shown) levels were determined in $\mathrm{MCH} 1 \mathrm{r}$ ko and wt mice using the quantitative lowperfusion rate microdialysis technique ( $A$ ) (Smith et al., 1992; Wang et al., 1997; Gerber et al., 2001) in four to six mice per genotype and conventional microdialysis in 11-14 mice per genotype $(B)$. Data are expressed in nanomol/liter concentration and represent the mean $\pm S E M$.

dopamine levels measured by low-perfusion rate microdialysis that we report are lower than previously published dopamine values measured using the no-net flux technique in the mouse NAc (Shippenberg et al., 2000; Chefer et al., 2003). All probe placements were verified histologically, and animals with probes located outside the NAc were excluded. It is possible that variations in the precise localization of probes within the mouse NAc contributed in part to the disparity between dopamine levels in the current study and published values. In fact, an NAc shell-core subregion dichotomy in mouse extracellular dopamine levels was shown with dopamine values in the shell significantly lower than those in the core (Zocchi et al., 2003). Importantly, methodological differences (e.g., length of time between probe implantation and testing, strain of mice) between the no-net flux experiments by Shippenberg et al. (2000) and Chefer et al. (2003) and the low-perfusion rate technique, as applied in the present study, may collectively account for discrepancies in our reported dopamine levels.

The basal efflux of monoamines within the NAc was not significantly higher in MCH1r ko than wt mice, but the enhanced locomotor response of ko mice to AMPH may indicate that the mesolimbic dopamine system is hyper-responsive to evoked dopamine efflux. Thus, we examined the effects of AMPH $(1,3$ $\mathrm{mg} / \mathrm{kg}$, i.p.) administration on dopamine, norepinephrine, serotonin, DOPAC, HVA, MHPG, and 5-HIAA levels within the NAc of ko and wt mice. No significant differences were observed in parent monoamine or metabolite concentrations in ko or wt mice after the administration of $1 \mathrm{mg} / \mathrm{kg}$ AMPH. However, there was a nonsignificant trend toward an increase in dopamine efflux (Fig. 6A) and a decrease in DOPAC and HVA levels (data not shown) in MCH1r ko mice. Robust increases in dopamine and norepinephrine efflux were observed in ko and wt mice after the injection of $3 \mathrm{mg} / \mathrm{kg}$ AMPH (Fig. $6 B-D$ ). The peak absolute concentration of evoked dopamine release was similar across genotypes (i.e., $2.7 \pm 0.5 \mathrm{pmol} / \mathrm{ml}$ and $2.8 \pm 0.8 \mathrm{pmol} / \mathrm{ml}$ in ko and wt mice, respectively) (Fig. $6 \mathrm{~B}, \mathrm{C}$ ). Norepinephrine levels were significantly elevated (Fig. $6 C, D$ ), and DOPAC levels were significantly decreased (data not shown), after the injection of 3 $\mathrm{mg} / \mathrm{kg}$ AMPH, but no genotype-dependent changes were observed. Significant changes were not detected in the levels of serotonin, 5-HIAA, HVA, or MHPG after the administration of $3 \mathrm{mg} / \mathrm{kg}$ AMPH.
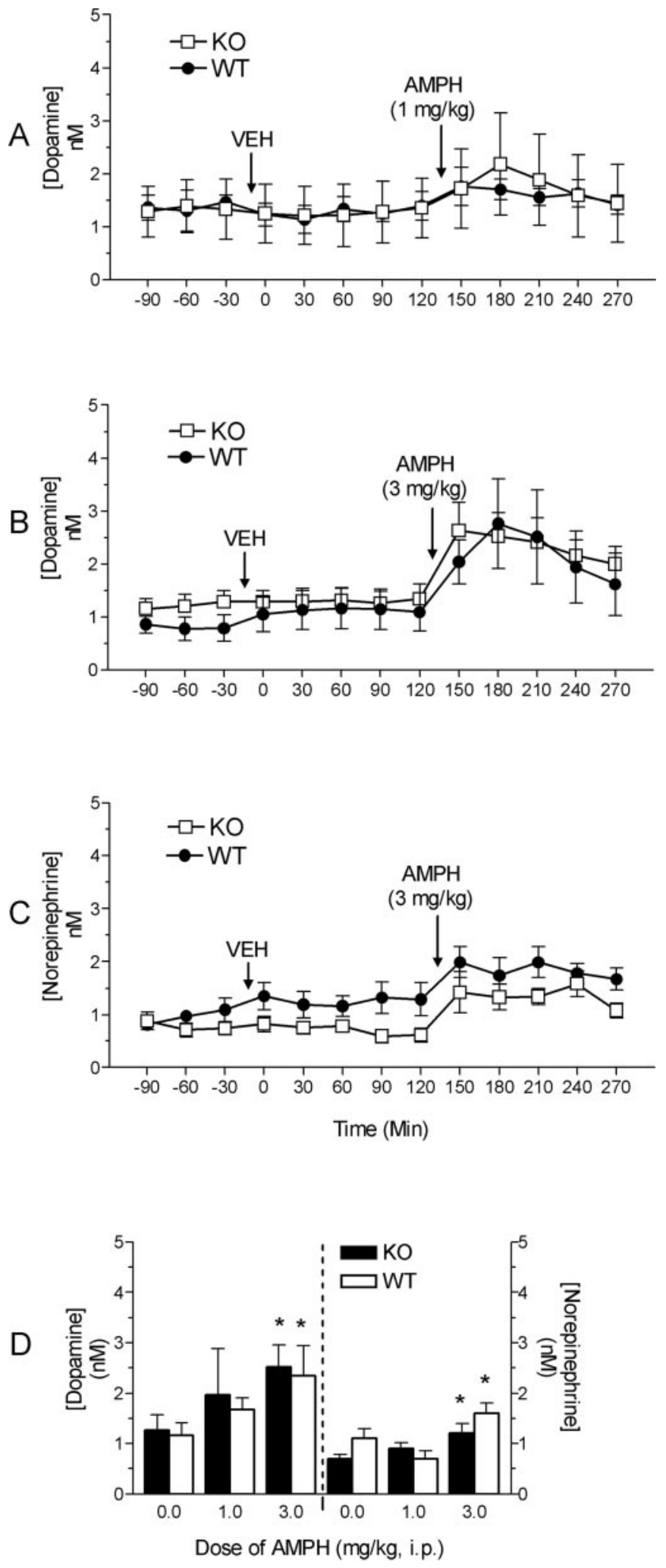

Figure 6. The effects of AMPH on dialysate dopamine and norepinephrine levels in the NAC are similar in $\mathrm{MCH} 1 \mathrm{r}$ ko and wt mice. $A$, Time course of NAc dopamine efflux before and after the administration of vehicle (VEH) (saline) and $1 \mathrm{mg} / \mathrm{kg}$ AMPH (i.p.) in four to five mice per genotype. B, C, Time courses of NAc dopamine and norepinephrine efflux after injection of saline or 3 $\mathrm{mg} / \mathrm{kg}$ AMPH (i.p.) in MCH1r ko and wt mice ( $n=6-8$ per genotype). D, Mean concentration of dopamine (left) and norepinephrine (right) in the first four samples collected after the administration of saline ( 0.0 ) or AMPH ( 1 and $3 \mathrm{mg} / \mathrm{kg}$, i.p.). Data are expressed in nanomol/liter concentration and represent the mean \pm SEM of the absolute values in the dialysate at each time point. ${ }^{*} p<0.05$ versus saline. 


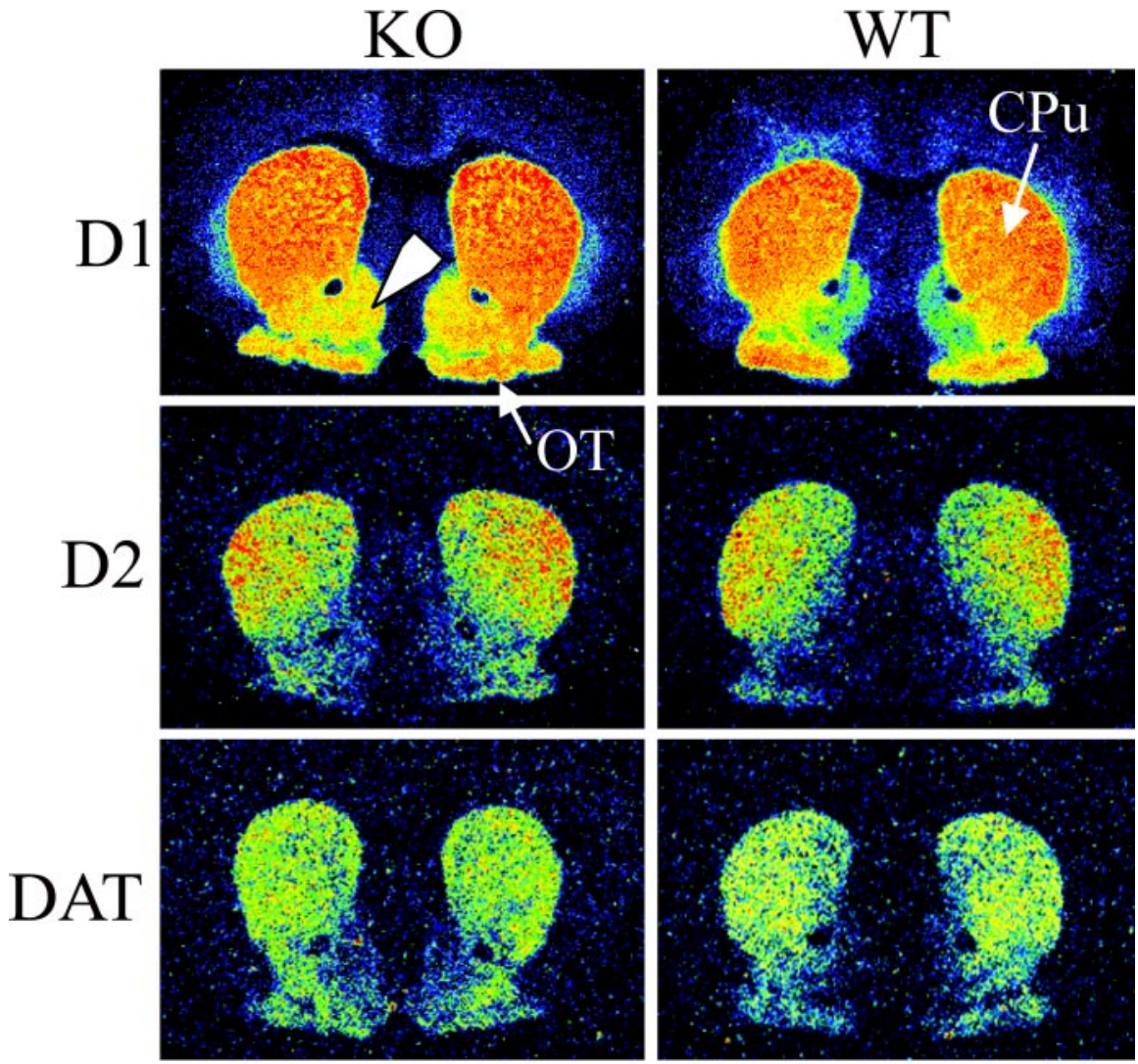

Figure 7. Representative autoradiographic localizations of $\left[{ }^{3} \mathrm{H}\right]-\mathrm{SCH} 23390\left(\mathrm{D}_{1}\right),\left[{ }^{3} \mathrm{H}\right]$-raclopride $\left(\mathrm{D}_{2}\right)$, and $\left[{ }^{3} \mathrm{H}\right]-$ WIN 35,428 (DAT) binding sites within the NAc core and shell, $0 \mathrm{~T}$, and CPu at approximately bregma plus $1.1 \mathrm{~mm}$. Mesolimbic $\mathrm{D}_{1}$ and $\mathrm{D}_{2}$ receptors are upregulated within the NAc and OT in MCH1r ko mice, compared with wt mice. Note the increased binding within the NAc shell (arrowhead) in ko mice. Quantitative receptor autoradiography was performed as described in Materials and Methods. The highest binding levels appear as red or orange.

\section{Upregulation of mesolimbic $\mathrm{D}_{1}$ and $\mathrm{D}_{2}$ receptors and norepinephrine transporter in $\mathrm{MCH} 1 \mathrm{r}$ ko mice}

The increased sensitivity to AMPH and $\mathrm{D}_{1}$ agonist-induced locomotor activity in the absence of changes in dopamine levels in $\mathrm{MCH} 1 \mathrm{r}$ ko mice indicates that mesolimbic dopamine receptors may be upregulated. Therefore, we used quantitative autoradiography to localize $D_{1}$ and $D_{2}$ receptors, dopamine transporters (DATs), norepinephrine transporters (NETs), and serotonin transporters (SERT) within the NAc core (NAcC), NAc shell (NAcSh), VTA, OT, CPu, globus pallidus (GP), and substantia nigra (SN) of MCH1r ko and wt mice (Figs. 7, 8; Table 1).

$\left[{ }^{3} \mathrm{H}\right]-\mathrm{SCH} 23390$ and $\left[{ }^{3} \mathrm{H}\right]$-raclopride binding was significantly higher within mesolimbic brain regions (e.g., NAc, OT, VTA) but not within nigrostriatal dopamine system structures (e.g., SN, CPu, GP) in MCH1r ko mice (Fig. 8). The results from $\left[{ }^{3} \mathrm{H}\right]$-WIN35,428, $\left[{ }^{3} \mathrm{H}\right]$-nisoxetine, and $\left[{ }^{3} \mathrm{H}\right]$-citalopram binding are outlined in Table 1 . Within the NAcSh, $\left[{ }^{3} \mathrm{H}\right]-\mathrm{SCH} 23390$, $\left[{ }^{3} \mathrm{H}\right]$-raclopride, and $\left[{ }^{3} \mathrm{H}\right]$-nisoxetine binding was significantly higher in ko than wt mice $(284,300$, and $367 \%$, respectively; $t=$ $2.4-4.73 ; p=0.04-0.002)$, whereas $\left[{ }^{3} \mathrm{H}\right]$-citalopram binding was significantly lower in ko than wt mice $(41 \% ; t=2.8 ; p=$ 0.02 ). No statistically significant differences were observed with $\left[{ }^{3} \mathrm{H}\right]$-WIN35,428 binding to the DAT in the areas examined. Within the NAcC, $\left[{ }^{3} \mathrm{H}\right]-\mathrm{SCH} 23390$ and $\left[{ }^{3} \mathrm{H}\right]$-raclopride binding were slightly, but significantly, higher in ko than wt mice (124 and $129 \%$, respectively; $t=2.6-2.7 ; p=0.03)$. Small but significantly higher $\left[{ }^{3} \mathrm{H}\right]-\mathrm{SCH} 23390$ binding within the VTA (150\%) and $\left[{ }^{3} \mathrm{H}\right]$-raclopride binding within the OT $(134 \%)$ was observed in ko compared with wt mice $(t=2.8 ; p=$ $0.02 ; t=3.7 ; p=0.01$, respectively). Within the GP, $\left[{ }^{3} \mathrm{H}\right]$-nisoxetine binding was significantly higher (350\%) in ko than wt mice $(t=2.6 ; p=0.03)$. No significant differences in ligand binding were observed within the $\mathrm{CPu}$ or $\mathrm{SN}$ of ko compared with wt mice.

\section{Discussion}

MCH1r ko mice were found to be hyperactive, hypermetabolic, and lean (Chen et al., 2002; Marsh et al., 2002). The MCH system is unique among orexigenic neuropeptides, because $\mathrm{MCH} 1 \mathrm{r}$ receptor expression is dense within dopamine-rich mesolimbic brain regions such as the NAc and VTA (Hervieu et al., 2000; Saito et al., 2001). Therefore, we tested the hypothesis that MCH1r deletion causes mesolimbic dopamine system dysregulation and that an altered dopaminergic state provides a neurobiological basis for the MCH1r ko mouse phenotype.

We show behavioral and neurobiological evidence that MCH1r ko mice are hypersensitive to mesolimbic dopamine neurotransmission. First, MCH1r ko mice exhibit persistent hyperactivity in response to a novel or familiar environment and are behaviorally hyper-responsive to AMPH or $\mathrm{D}_{1}$ receptor stimulation, but not $\mathrm{D}_{2}$ activation by quinpirole, compared with wt mice (Figs. 2, 3). Lesions of the NAc dopamine system reduce spontaneous locomotion and AMPH-evoked hyperactivity (Koob et al., 1981), and restoration of NAc dopamine re-establishes exploratory activity in dopamine-depleted mice (Szczypka et al., 2001). Therefore, behavioral hyperactivity and hyper-responsiveness to dopamine-evoked locomotion may be the manifestation of underlying changes in mesolimbic dopaminergic function. We directly tested whether hyperactivity and hyper-responsiveness to SKF-38393 and AMPH-evoked locomotion in MCH1r ko mice is associated with a mesolimbic hyperdopaminergic state.

Tissue contents of dopamine, serotonin, DOPAC, HVA, MHPG, and 5-HIAA within the NAc and Cpu were determined, and we used in vivo microdialysis to measure the extracellular concentrations of dopamine, norepinephrine, serotonin, DOPAC, HVA, MHPG, and 5-HIAA within the NAc. Lowperfusion flow rate and conventional microdialysis techniques were used to assess basal dialysate concentrations, because inherent variance associated with the conventional method may mask small but significant differences (Shippenberg et al., 1999). In the present study, no significant differences in basal or AMPHevoked tissue levels of monoamines or metabolites within the $\mathrm{NAc}$ or $\mathrm{CPu}$ were found in MCH1r ko, compared with wt mice (Fig. 4). MCH1r ko and wt mice also did not significantly differ in basal or AMPH-induced extracellular monoamine concentrations within the NAc (Figs. 5, 6). Dopamine is released into the $\mathrm{NAc}$ by neurons originating in the VTA, and $\mathrm{MCH}$ does not increase the firing rate of VTA neurons (Korotkova et al., 2003). 


\section{$[3 \mathrm{H}]-\mathrm{SCH} 23390$ Binding}

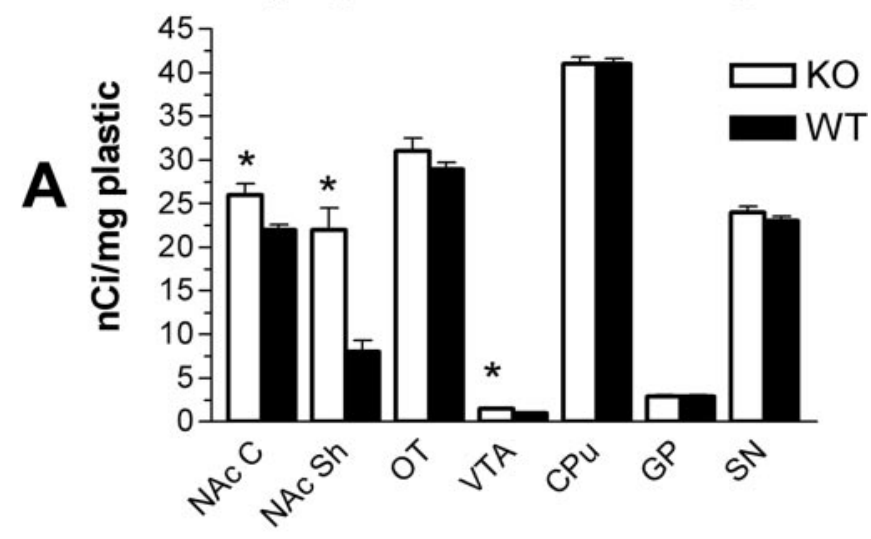

[3H]-raclopride Binding

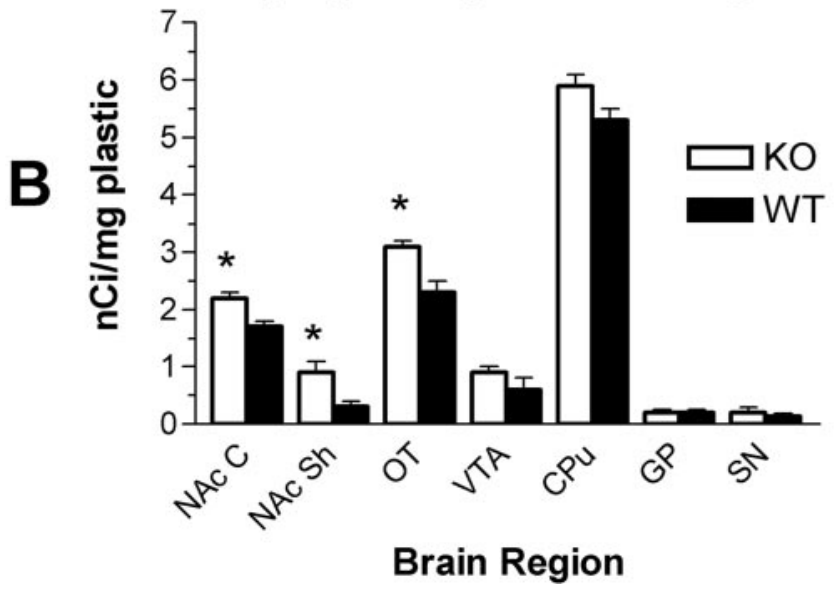

Figure 8. $\quad D_{1}$ and $D_{2}$ receptor binding within mesolimbic but not other brain regions in MCH1r ko mice is upregulated. Autoradiographic localization of $\left[{ }^{3} \mathrm{H}\right]-\mathrm{SCH} 23390\left(\mathrm{D}_{1}\right)(A)$ and $\left[{ }^{3} \mathrm{H}\right]$-raclopride $\left(\mathrm{D}_{2}\right)(B)$ binding sites within mesolimbic and nigrostriatal dopamine system brain regions in $\mathrm{MCH} 1 \mathrm{r}$ ko and wt mice ( $n=5$ per genotype). Quantitative receptor autoradiography was performed as described in Materials and Methods. ${ }^{*} p<0.05$ ko versus wt.

Therefore, the MCH1r does not appear to have a major role in modulating meso-accumbens dopamine release.

The actions of extracellular dopamine are terminated by reuptake through the DAT and NET (Amara and Kuhar, 1993; Yamamoto and Novotney, 1998). The DAT, NET, and SERT have high affinity for AMPH, and AMPH causes reversetransport of cytoplasmic monoamines through these carriers (Wall et al., 1995; Pifl et al., 1999). In the absence of DAT, mice are hyperdopaminergic and hyperactive (Giros et al., 1996). We hypothesized that downregulation of DAT in MCH1r ko mice may account for their hyperactive phenotype. We quantified the DAT, NET, and SERT in MCH1r ko and wt mice. DAT levels did not significantly differ between the genotypes (Table 1). Consistent with the microdialysis data, it is unlikely that changes in DAT are responsible for the phenotype of MCH1r ko mice. Alternatively, the vesicular pool of dopamine available for release may be more important than the expression of DAT in modulating the monoamine-releasing effects of AMPH (Jones et al., 1998), but we demon- strated that MCH1r ko and wt mice do not differ in tissue levels of dopamine or its metabolites (Fig. 4). The phenotype of MCH1r ko mice does not appear to depend on neuroadaptations in DAT function.

In contrast, the multifold increase in NET in MCH1r ko mice (Table 1) leaves open the possibility that AMPH super-sensitivity in MCH1r ko mice is partly attributable to increased AMPHinduced reverse-transport of dopamine through the NET. It is also possible that increased NET levels in MCH1r ko mice may mask a genotype-dependent difference in AMPH-evoked dopamine or norepinephrine efflux. Norepinephrine and serotonin systems are directly implicated in modulating anxiety and depression (Ressler and Nemeroff, 2000), and differences in NET and SERT expression may indicate a neurobiological substrate for the purported anxiolytic and antidepressant properties of an MCH1r antagonist (Borowsky et al., 2002). SNAP-7941, a novel selective $\mathrm{MCH} 1 \mathrm{r}$ antagonist, was effective at decreasing immobility in the rat forced-swim test, reducing the number of maternal separation-induced vocalizations and increasing social interaction among unfamiliar rats (Borowsky et al., 2002). These results parallel the effects of known antidepressant and anxiolytic drugs (Lucki, 1997; Rupniak et al., 2000; File and Seth, 2003). Additional studies directed at elucidating the precise role of NET and SERT changes in the MCH1r ko mice are ongoing.

Given that MCH1r ko mice are super-sensitive to SKF-38393induced hyperactivity (Fig. $3 A$ ), we explored whether dopamine receptor changes underlie the MCH1r ko mouse phenotype. We showed that $D_{1}$ and $D_{2}$ receptors are significantly upregulated within brain regions that comprise the mesolimbic (i.e., VTA, NAc, OT), but not nigrostriatal (i.e., substantia nigra, caudateputamen), dopamine system within MCH1r ko mice (Fig. 8). Activation of postsynaptic dopamine receptors inhibits GABAergic projections to the ventral pallidum (VP), which, in turn, increases locomotion (Mogenson and Nielsen, 1983; Koob and Swerdlow, 1988). $\mathrm{D}_{1}$ receptors are required for the expression of SKF-38393-mediated hyperactivity (Xu et al., 1994b), and hyperlocomotion (Xu et al., 2000) and fos-like immunoreactivity (Graybiel et al., 1990) induced by AMPH is, in part, mediated by $\mathrm{D}_{1}$ receptor activation. Moreover, mesolimbic dopamine receptors are known to mediate goal-directed, exploratory activity (Dreher and Jackson, 1989; Xu et al., 1994a; Szczypka et al., 2001). Thus, it is evident that altered $D_{1}$ receptor-mediated neurotransmission is a vital neural substrate of the hyperactive phenotype of MCH1r ko mice.

An upregulation of postsynaptic $\mathrm{D}_{2}$ receptors may contribute to hyperactivity in MCH1r ko mice by disinhibiting NAc GABAergic efferents to the VP. However, $\mathrm{D}_{2}$ receptors within the NAc are also presynaptic autoreceptors localized on dopaminergic and glutamatergic neurons within the NAc (Yang and Mogenson, 1986; Wu et al., 1993). Activation of $\mathrm{D}_{2}$ autoreceptors sup-
Table 1. Dopamine, norepinephrine, and serotonin transporter localization in MCH1r ko and wt mice

\begin{tabular}{llllccr}
\hline Brain region & $\left.{ }^{3} \mathrm{H}\right]-$ WIN35,428 & \multicolumn{3}{c}{$\left[{ }^{3} \mathrm{H}\right]$-Nisoxetine } & \multicolumn{3}{c}{$\left[{ }^{3} \mathrm{H}\right]$-Citalopram } \\
\hline Nucleus accumbens & \multicolumn{1}{c}{ k0 } & wt & k0 & wt & ko & wt \\
Core & $1.8 \pm 0.4$ & $1.7 \pm 0.1$ & $0.7 \pm 0.1$ & $0.2 \pm 0.2$ & $10.6 \pm 0.6$ & $9.3 \pm 1.1$ \\
Shell & $0.4 \pm 0.06$ & $0.5 \pm 0.05$ & $1.1 \pm 0.3^{*}$ & $0.3 \pm 0.1$ & $7.0 \pm 2.7^{*}$ & $16.9 \pm 2.3$ \\
Olfactory tubercle & $1.4 \pm 0.07$ & $1.4 \pm 0.1$ & $0.5 \pm 0.2$ & $0.3 \pm 0.1$ & $17.3 \pm 0.6$ & $21.5 \pm 1.9$ \\
Ventral tegmental area & $0.5 \pm 0.06$ & $0.4 \pm 0.1$ & $2.7 \pm 0.2$ & $2.1 \pm 0.3$ & $34.5 \pm 1.2$ & $34.5 \pm 3.0$ \\
Caudate putamen & $2.3 \pm 0.1$ & $2.2 \pm 0.1$ & $0.2 \pm 0.4$ & $0.03 \pm 0.1$ & $6.0 \pm 0.4$ & $6.0 \pm 0.8$ \\
Globus pallidus & $0.1 \pm 0.05$ & $0.1 \pm 0.03$ & $0.7 \pm 0.1^{*}$ & $0.2 \pm 0.1$ & $13.8 \pm 0.8$ & $16.1 \pm 2.3$ \\
Substantia nigra & $0.9 \pm 0.2$ & $0.8 \pm 0.1$ & $1.7 \pm 0.3$ & $1.0 \pm 0.1$ & $43.8 \pm 1.4$ & $49.3 \pm 3.8$ \\
\hline
\end{tabular}

Values are the means \pm SEM in nanoCurie/milligram plastic. A minimum of four bilateral readings was taken per animal ( $n=5$ animals per genotype) Sections were procured and incubated as described in Materials and Methods. ${ }^{*} p<0.05$, ko versus wt using unpaired two-tailed Student's t test. 
presses locomotor activity (Mogenson and Wu, 1991; Frantz and Van Hartesveldt, 1995). We showed that the $\mathrm{D}_{2}$ agonist, quinpirole, reduced activity similarly in both $\mathrm{MCH} 1 \mathrm{r}$ ko and wt mice (Fig. 3C). Thus, if $\mathrm{D}_{2}$ autoreceptors in MCH1r ko mice are upregulated, the effect on locomotor activity is overridden by upregulated $D_{1}$ and postsynaptic $D_{2}$ receptors. We tested a broad range of doses and most likely would have detected supersensitivity to $\mathrm{D}_{2}$-mediated hypoactivation if it developed in MCH1r ko mice.

The relationship of mesolimbic dopamine receptor upregulation with the role of MCH1r in feeding is unclear, because the administration of dopamine receptor agonists and antagonists reduces food intake in rodents (Heffner et al., 1977; Johnson and Bruno, 1990; Salamone et al., 1990; Pitts and Horvitz, 2000). However, increased sensitivity of the mesolimbic monoamine systems may be indicative of altered reward processing mechanisms. The mesolimbic dopamine system has an established role in drug abuse and feeding, and there is nascent interest in the role of MCH1r in modulating responses to reinforcing stimuli (Saper et al., 2002; DiLeone et al., 2003). Additional investigation into the precise relationship of the $\mathrm{MCH}$ system with reward is underway and may provide new insight into treating drug addiction and feeding disorders.

It is noteworthy that the MCH1r ko and wt mice used in these studies had a mixed $129 \mathrm{SvJ} \times \mathrm{C} 57 \mathrm{BL} / 6$ genetic background. Genetic background is known to influence various behaviors (Crawley et al., 1997), and the phenotype of these mice may not be independent of genetic background. However, the phenotype of our MCH1r ko and wt mouse lines mirrors the phenotype of MCH1r ko and wt mice on a 129 SvEv $\times$ C57BL/6 hybrid background (Marsh et al., 2002). In addition, 129SvEv and C57BL/6 mice behave similarly in various tests, including rotorod performance and open-field exploration (Bothe et al., 2004).

In conclusion, we show that MCH1r ko mice are supersensitive to activation of postsynaptic mesolimbic dopamine receptors and that upregulation of these receptors is the fundamental neural substrate of the MCH1r ko mouse phenotype. In addition, we demonstrated that MCH1r ko mice have significant alterations in mesolimbic norepinephrine and serotonin systems that may contribute to the phenotype. We hypothesize that $\mathrm{MCH} 1 \mathrm{r}$ regulates mesolimbic monoamine neurotransmission and that genetic deletion of the MCH1r results in increased sensitivity to mesolimbic system activity. Alternatively, $\mathrm{MCH}$ may be important for the normal development of mesolimbic systems, and deletion of the MCH1r prevents their normal growth. Either way, our results are consistent with an important interaction of $\mathrm{MCH} 1 \mathrm{r}$ with the function of mesolimbic brain regions. Limbic system dopamine, norepinephrine, and serotonin have vital roles in craving and affective neuropsychiatric disorders, and modulation by MCH1r of these neurotransmitters may be an important therapeutic mechanism in the treatment of these diseases.

\section{References}

Amara SG, Kuhar MJ (1993) Neurotransmitter transporters: recent progress. Annu Rev Neurosci 16:73-93.

An S, Cutler G, Zhao JJ, Huang SG, Tian H, Li W, Liang L, Rich M, Bakleh A, Du J, Chen JL, Dai K (2001) Identification and characterization of a melanin-concentrating hormone receptor. Proc Natl Acad Sci USA 98:7576-7581.

Bittencourt JC, Presse F, Arias C, Peto C, Vaughan J, Nahon JL, Vale W, Sawchenko PE (1992) The melanin-concentrating hormone system of the rat brain: an immuno- and hybridization histochemical characterization. J Comp Neurol 319:218-245.

Borowsky B, Durkin MM, Ogozalek K, Marzabadi MR, DeLeon J, Lagu B,
Heurich R, Lichtblau H, Shaposhnik Z, Daniewska I, Blackburn TP, Branchek TA, Gerald C, Vaysse PJ, Forray C (2002) Antidepressant, anxiolytic and anorectic effects of a melanin-concentrating hormone-1 receptor antagonist. Nat Med 8:825-830.

Bothe GW, Bolivar VJ, Vedder MJ, Geistfeld JG (2004) Genetic and behavioral differences among five inbred mouse strains commonly used in the production of transgenic and knockout mice. Genes Brain Behav 3:149-157.

Chambers J, Ames RS, Bergsma D, Muir A, Fitzgerald LR, Hervieu G, Dytko GM, Foley JJ, Martin J, Liu WS, Park J, Ellis C, Ganguly S, Konchar S, Cluderay J, Leslie R, Wilson S, Sarau HM (1999) Melanin-concentrating hormone is the cognate ligand for the orphan G-protein-coupled receptor SLC-1. Nature 400:261-265.

Chefer VI, Kieffer BL, Shippenberg TS (2003) Basal and morphine-evoked dopaminergic neurotransmission in the nucleus accumbens of MOR- and DOR-knockout mice. Eur J Neurosci 18:1915-1922.

Chen Y, Hu C, Hsu CK, Zhang Q, Bi C, Asnicar M, Hsiung HM, Fox N, Slieker LJ, Yang DD, Heiman ML, Shi Y (2002) Targeted disruption of the melanin-concentrating hormone receptor-1 results in hyperphagia and resistance to diet-induced obesity. Endocrinology 143:2469-2477.

Crawley JN, Belknap JK, Collins A, Crabbe JC, Frankel W, Henderson N, Hitzemann RJ, Maxson SC, Miner LL, Silva AJ, Wehner JM, WynshawBoris A, Paylor R (1997) Behavioral phenotypes of inbred mouse strains: implications and recommendations for molecular studies. Psychopharmacology (Berl) 132:107-124.

Dawson TM, Gehlert DR, McCabe RT, Barnett A, Wamsley JK (1986) D-1 dopamine receptors in the rat brain: a quantitative autoradiographic analysis. J Neurosci 6:2352-2365.

DiLeone RJ, Georgescu D, Nestler EJ (2003) Lateral hypothalamic neuropeptides in reward and drug addiction. Life Sci 73:759-768.

Dreher JK, Jackson DM (1989) Role of $\mathrm{D}_{1}$ and $\mathrm{D}_{2}$ dopamine receptors in mediating locomotor activity elicited from the nucleus accumbens of rats. Brain Res 487:267-277.

File SE, Seth P (2003) A review of 25 years of the social interaction test. Eur J Pharmacol 463:35-53.

Fink JS, Smith GP (1980) Mesolimbicocortical dopamine terminal fields are necessary for normal locomotor and investigatory exploration in rats. Brain Res 199:359-384.

Franklin KBJ, Paxinos G (1997) The mouse brain in stereotaxic coordinates. San Diego: Academic.

Frantz KJ, Van Hartesveldt C (1995) Sulpiride antagonizes the biphasic locomotor effects of quinpirole in weanling rats. Psychopharmacology (Berl) 119:299-304.

Gehlert DR, Schoepp DD (1992) Striatal quinolinic acid lesions increase [3H]WIN 35,428 binding to the dopamine transporter. Neurochem Int 21:581-584.

Gehlert DR, Schober DA, Gackenheimer SL (1995) Comparison of (R)$[3 \mathrm{H}]$ tomoxetine and $(\mathrm{R} / \mathrm{S})-[3 \mathrm{H}]$ nisoxetine binding in rat brain. J Neurochem 64:2792-2800.

Gerber DJ, Sotnikova TD, Gainetdinov RR, Huang SY, Caron MG, Tonegawa S (2001) Hyperactivity, elevated dopaminergic transmission, and response to amphetamine in M1 muscarinic acetylcholine receptordeficient mice. Proc Natl Acad Sci USA 98:15312-15317.

Giros B, Jaber M, Jones SR, Wightman RM, Caron MG (1996) Hyperlocomotion and indifference to cocaine and amphetamine in mice lacking the dopamine transporter. Nature 379:606-612.

Graybiel AM, Moratalla R, Robertson HA (1990) Amphetamine and cocaine induce drug-specific activation of the c-fos gene in striosome-matrix compartments and limbic subdivisions of the striatum. Proc Natl Acad Sci USA 87:6912-6916.

Heffner TG, Zigmond MJ, Stricker EM (1977) Effects of dopaminergic agonists and antagonists on feeding in intact and 6-hydroxydopaminetreated rats. J Pharmacol Exp Ther 201:386-399.

Hervieu GJ, Cluderay JE, Harrison D, Meakin J, Maycox P, Nasir S, Leslie RA (2000) The distribution of the mRNA and protein products of the melanin-concentrating hormone $(\mathrm{MCH})$ receptor gene, slc-1, in the central nervous system of the rat. Eur J Neurosci 12:1194-1216.

Hoebel BG, Hernandez L, Schwartz DH, Mark GP, Hunter GA (1989) Microdialysis studies of brain norepinephrine, serotonin, and dopamine release during ingestive behavior. Theoretical and clinical implications. Ann NY Acad Sci 575:171-191, 192-173.

Johnson BJ, Bruno JP (1990) $\mathrm{D}_{1}$ and $\mathrm{D}_{2}$ receptor contributions to ingestive 
and locomotor behavior are altered after dopamine depletions in neonatal rats. Neurosci Lett 118:120-123.

Jones SR, Gainetdinov RR, Wightman RM, Caron MG (1998) Mechanisms of amphetamine action revealed in mice lacking the dopamine transporter. J Neurosci 18:1979-1986.

Kelley AE, Berridge KC (2002) The neuroscience of natural rewards: relevance to addictive drugs. J Neurosci 22:3306-3311.

Knable MB, Hyde TM, Herman MM, Carter JM, Bigelow L, Kleinman JE (1994a) Quantitative autoradiography of dopamine- $\mathrm{D}_{1}$ receptors, $\mathrm{D}_{2}$ receptors, and dopamine uptake sites in postmortem striatal specimens from schizophrenic patients. Biol Psychiatry 36:827-835.

Knable MB, Hyde TM, Egan MF, Tosayali M, Wyatt RJ, Kleinman JE (1994b) Quantitative autoradiography of striatal dopamine $\mathrm{D}_{1}, \mathrm{D}_{2}$ and re-uptake sites in rats with vacuous chewing movements. Brain Res 646:217-222.

Koob GF, Bloom FE (1988) Cellular and molecular mechanisms of drug dependence. Science 242:715-723.

Koob GF, Swerdlow NR (1988) The functional output of the mesolimbic dopamine system. Ann NY Acad Sci 537:216-227.

Koob GF, Stinus L, Le Moal M (1981) Hyperactivity and hypoactivity produced by lesions to the mesolimbic dopamine system. Behav Brain Res 3:341-359.

Korotkova TM, Sergeeva OA, Eriksson KS, Haas HL, Brown RE (2003) Excitation of ventral tegmental area dopaminergic and nondopaminergic neurons by orexins/hypocretins. J Neurosci 23:7-11.

Lucki I (1997) The forced swimming test as a model for core and component behavioral effects of antidepressant drugs. Behav Pharmacol 8:523-532.

Ludwig DS, Tritos NA, Mastaitis JW, Kulkarni R, Kokkotou E, Elmquist J, Lowell B, Flier JS, Maratos-Flier E (2001) Melanin-concentrating hormone overexpression in transgenic mice leads to obesity and insulin resistance. J Clin Invest 107:379-386.

Marsh DJ, Weingarth DT, Novi DE, Chen HY, Trumbauer ME, Chen AS, Guan XM, Jiang MM, Feng Y, Camacho RE, Shen Z, Frazier EG, Yu H, Metzger JM, Kuca SJ, Shearman LP, Gopal-Truter S, MacNeil DJ, Strack AM, MacIntyre DE, Van der Ploeg LH, Qian S (2002) Melaninconcentrating hormone 1 receptor-deficient mice are lean, hyperactive, and hyperphagic and have altered metabolism. Proc Natl Acad Sci USA 99:3240-3245.

Mogenson GJ, Nielsen MA (1983) Evidence that an accumbens to subpallidal GABAergic projection contributes to locomotor activity. Brain Res Bull 11:309-314.

Mogenson GJ, Wu M (1991) Effects of administration of dopamine $D_{2}$ agonist quinpirole on exploratory locomotion. Brain Res 551:216-220.

Nahon JL (1994) The melanin-concentrating hormone: from the peptide to the gene. Crit Rev Neurobiol 8:221-262.

Perry KW, Fuller RW (1997) Fluoxetine increases norepinephrine release in rat hypothalamus as measured by tissue levels of MHPG-SO4 and microdialysis in conscious rats. J Neural Transm 104:953-966.

Pifl C, Agneter E, Drobny H, Sitte HH, Singer EA (1999) Amphetamine reverses or blocks the operation of the human noradrenaline transporter depending on its concentration: superfusion studies on transfected cells. Neuropharmacology 38:157-165.

Pitts SM, Horvitz JC (2000) Similar effects of $D(1) / D(2)$ receptor blockade on feeding and locomotor behavior. Pharmacol Biochem Behav 65:433-438.

Qu D, Ludwig DS, Gammeltoft S, Piper M, Pelleymounter MA, Cullen MJ, Mathes WF, Przypek R, Kanarek R, Maratos-Flier E (1996) A role for melanin-concentrating hormone in the central regulation of feeding behaviour. Nature 380:243-247.

Ressler KJ, NemeroffCB (2000) Role of serotonergic and noradrenergic systems in the pathophysiology of depression and anxiety disorders. Depress Anxiety 12[Suppl 1]:2-19.

Rossi M, Choi SJ, O'Shea D, Miyoshi T, Ghatei MA, Bloom SR (1997) Melaninconcentrating hormone acutely stimulates feeding, but chronic administration has no effect on body weight. Endocrinology 138:351-355.

Rupniak NM, Carlson EC, Harrison T, Oates B, Seward E, Owen S, de Felipe C, Hunt S, Wheeldon A (2000) Pharmacological blockade or genetic deletion of substance $\mathrm{P}(\mathrm{NK}(1))$ receptors attenuates neonatal vocalisation in guinea-pigs and mice. Neuropharmacology 39:1413-1421.

Sailer AW, Sano H, Zeng Z, McDonald TP, Pan J, Pong SS, Feighner SD, Tan CP, Fukami T, Iwaasa H, Hreniuk DL, Morin NR, Sadowski SJ, Ito M,
Bansal A, Ky B, Figueroa DJ, Jiang Q, Austin CP, MacNeil DJ, et al. (2001) Identification and characterization of a second melaninconcentrating hormone receptor, MCH-2R. Proc Natl Acad Sci USA 98:7564-7569.

Saito Y, Nothacker HP, Wang Z, Lin SH, Leslie F, Civelli O (1999) Molecular characterization of the melanin-concentrating-hormone receptor. Nature 400:265-269.

Saito Y, Cheng M, Leslie FM, Civelli O (2001) Expression of the melaninconcentrating hormone $(\mathrm{MCH})$ receptor mRNA in the rat brain. J Comp Neurol 435:26-40.

Salamone JD, Zigmond MJ, Stricker EM (1990) Characterization of the impaired feeding behavior in rats given haloperidol or dopamine-depleting brain lesions. Neuroscience 39:17-24.

Saper CB, Chou TC, Elmquist JK (2002) The need to feed: homeostatic and hedonic control of eating. Neuron 36:199-211.

Shimada M, Tritos NA, Lowell BB, Flier JS, Maratos-Flier E (1998) Mice lacking melanin-concentrating hormone are hypophagic and lean. Nature 396:670-674.

Shippenberg TS, He M, Chefer V (1999) The use of microdialysis in the mouse: conventional versus quantitative techniques. Psychopharmacology (Berl) 147:33-34.

Shippenberg TS, Hen R, He M (2000) Region-specific enhancement of basal extracellular and cocaine-evoked dopamine levels following constitutive deletion of the Serotonin(1B) receptor. J Neurochem 75:258-265.

Smith AD, Olson RJ, Justice Jr JB (1992) Quantitative microdialysis of dopamine in the striatum: effect of circadian variation. J Neurosci Methods 44:33-41.

Szczypka MS, Kwok K, Brot MD, Marck BT, Matsumoto AM, Donahue BA, Palmiter RD (2001) Dopamine production in the caudate putamen restores feeding in dopamine-deficient mice. Neuron 30:819-828.

Takekawa S, Asami A, Ishihara Y, Terauchi J, Kato K, Shimomura Y, Mori M, Murakoshi H, Suzuki N, Nishimura O, Fujino M (2002) T-226296: a novel, orally active and selective melanin-concentrating hormone receptor antagonist. Eur J Pharmacol 438:129-135.

Tan CP, Sano H, Iwaasa H, Pan J, Sailer AW, Hreniuk DL, Feighner SD, Palyha OC, Pong SS, Figueroa DJ, Austin CP, Jiang MM, Yu H, Ito J, Ito M, Guan XM, MacNeil DJ, Kanatani A, Van der Ploeg LH, Howard AD (2002) Melanin-concentrating hormone receptor subtypes 1 and 2: species-specific gene expression. Genomics 79:785-792.

Wall SC, Gu H, Rudnick G (1995) Biogenic amine flux mediated by cloned transporters stably expressed in cultured cell lines: amphetamine specificity for inhibition and efflux. Mol Pharmacol 47:544-550.

Wang YM, Gainetdinov RR, Fumagalli F, Xu F, Jones SR, Bock CB, Miller GW, Wightman RM, Caron MG (1997) Knockout of the vesicular monoamine transporter 2 gene results in neonatal death and supersensitivity to cocaine and amphetamine. Neuron 19:1285-1296.

Wise RA, Bozarth MA (1985) Brain mechanisms of drug reward and euphoria. Psychiatr Med 3:445-460.

Wu M, Brudzynski SM, Mogenson GJ (1993) Differential effects of quinpirole in the nucleus accumbens depending on the initial level of locomotor activity. Brain Res Bull 32:395-398.

Xu M, Hu XT, Cooper DC, Moratalla R, Graybiel AM, White FJ, Tonegawa S (1994a) Elimination of cocaine-induced hyperactivity and dopaminemediated neurophysiological effects in dopamine $\mathrm{D}_{1}$ receptor mutant mice. Cell 79:945-955.

Xu M, Moratalla R, Gold LH, Hiroi N, Koob GF, Graybiel AM, Tonegawa S (1994b) Dopamine $\mathrm{D}_{1}$ receptor mutant mice are deficient in striatal expression of dynorphin and in dopamine-mediated behavioral responses. Cell 79:729-742.

Xu M, Guo Y, Vorhees CV, Zhang J (2000) Behavioral responses to cocaine and amphetamine administration in mice lacking the dopamine $\mathrm{D}_{1}$ receptor. Brain Res 852:198-207.

Yamamoto BK, Novotney S (1998) Regulation of extracellular dopamine by the norepinephrine transporter. J Neurochem 71:274-280.

Yang CR, Mogenson GJ (1986) Dopamine enhances terminal excitability of hippocampal-accumbens neurons via $\mathrm{D}_{2}$ receptor: role of dopamine in presynaptic inhibition. J Neurosci 6:2470-2478.

Zocchi A, Girlanda E, Varnier G, Sartori I, Zanetti L, Wildish GA, Lennon M, Mugnaini M, Heidbreder CA (2003) Dopamine responsiveness to drugs of abuse: a shell-core investigation in the nucleus accumbens of the mouse. Synapse 50:293-302. 